\title{
呈示視野と一致試行の出現確率が適合性効果に及ぼす影響 $(1)$
}

\author{
○吉崎一人 ${ }^{1} \cdot$ 藏冨恵 $^{2}$ \\ (1 愛知淑徳大学コミュニケーション学部・2愛知淑徳大学大学院心理学研究科) \\ キーワード: 視覚的注意, 認知的制御, 適合性効果
}

\begin{abstract}
Visual field and appearance probability in congruent/incongruent trials modulate compatibility effects (1)
Kazuhito YOSHIZAKI ${ }^{1}$ and Kei KURATOMI ${ }^{2}$

( ${ }^{1}$ Aichi Shukutoku University, ${ }^{2}$ Graduate School of Psychology, Aichi Shukutoku University)

Key words: visual attention, cognitive control, compatibility effect
\end{abstract}

\section{目 的}

我々は，頻繁に使用される反応であっても，経験や状況， 文脈に応じて，これまで使用してきた方略をより適切なもの へと調整する能力を持つ。このような認知的制御機能は，視 覚的注意においても検討されている。例えば, Gratton, Coles, \& Donchin（1992）は，フランカー課題を用いて，ターゲット とフランカーの適合性の出現確率をブロック内で操作した。 その結果, 観察される適合性効果の大きさが, 一致試行の出 現確率の低いブロックよりも, 高いブロックにおいて, 増加 した。これは不一致試行を多く経験した事態には, 競合を解 消寸る経験が多くなり,このことがフランカーの排除を強め, 適合性効果の減少を導くと解釈される。一方, 一致試行が多 い事態には，競合解消の経験が少なくなり，フランカーを排 除する傾向が弱く, 適合性効果は増大寸ると考えられる。

さらにこれらの調整は, 左右各視野で独立して行われるこ とも明らかになっている (Corballis \& Gratton, 2003; 蔵冨・吉 崎, 2010)。これらの研究では, 左右各視野における一致試行 の出現確率を操作することによって, 各視野の適合性効果が 左右視野独立に変動することが明らかとなった。これは，左 右各半球で認知的制御が働いている可能性を示唆した。

本研究は, 蔵富・吉崎(2010) とは異なる呈示布置, 並びに 文字列（図 1 参照）を用いて, 左右視野における一致試行の 出現確率が適合性効果に及ぼす影響を検討する。これまでの 知見が正しければ，一致試行の出現確率が高い視野の適合性 効果は，低い視野よりも大きくなることが予想された。

\section{方 法}

要因計画 呈示視野 (左視野 /右視野) $\times$ 一致試行の出現 確率 $(75 \%$ 視野 $/ 25 \%$ 視野 $) \times$ メーゲットとフランカーの適 合性（一致/不一致）の 3 要因実験参加者内計画。実験参加 者 正常視力もしくは矯正視力を有した 18～31 歳 $(M=21.2$, $S D=2.94 ）$ の右手利き大学生および大学院生 16 名（女性 12 名)。刺激 ターゲットおよびフランカーは “X”と“N”。刺 激の大きさは. $62^{\circ} \times .77^{\circ}$ 。 5 文字の文字列は, ターゲットを 中心とし 4 方向を囲むようにフランカーが呈示(図 1 参照)。 文字間の距離は $1.08^{\circ}$ 。凝視点からターゲットの距離は水平 方向に $4.65^{\circ}$ ，垂直方向に $3.41^{\circ}$ で，4 箇所のうちいずれか に呈示。1 ブロック（64 試行）中，75\%視野条件においては 一致試行が 24 試行, 不一致試行が 8 試行, $25 \%$ 視野条件にお いては一致試行が 8 試行, 不一致試行が 24 試行であった。左 右視野の一方が $75 \%$ 視野条件のとき，もう一方の視野は $25 \%$ 視野条件であった。手続き 凝視点 $(500 \mathrm{~ms})$ の後, 刺激は $150 \mathrm{~ms}$ 呈示。課題は, 左右上下のいずれかに呈示される十字 型の文字列の中から, 中心の文字が “X”か “N”かをできる だけ速く,できるだけ正確に同定すること。反応はキー押し によって行われ, 反応には両手の人差し指を使用。6 64 試行か らなるブロックを 8 ブロック実施。本試行の前に練習試行(一 致試行の出現確率は $50 \%$ ）を実施。半数の実験参加者は, ま
ず左視野 $75 \%$ 視野条件（右視野 $25 \%$ 視野）で構成されたブロ ックを 4 ブロック実施し, 次に左視野 $25 \%$ 視野条件で構成さ れたブロックを 4 ブロック実施した。残り半数の実験参加者 は逆の順序で実施した。
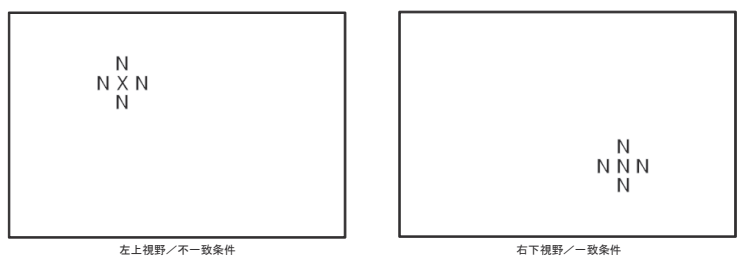

図 1 刺激呈示例

\section{結 果}

正答に要した反応時間を使用し, 呈示視野 $\times$ 一致試行の出 現確率×ターゲットとフランカーの適合性の分散分析を行っ た。その結果, 一致試行の出現確率×ターゲットとフランカ 一の適合性において, 有意な交互作用が見られた $(F(1,15)=$ $\left.5.41, p<.05, \eta_{\mathrm{p}}{ }^{2}=.26\right)$ 。これは, 適合性効果が, $25 \%$ 視野条件 $(57 \mathrm{~ms})$ に比べ, $75 \%$ 視野条件 $(70 \mathrm{~ms})$ で増加したことの反 映であった。その他の交互作用は見られなかった。

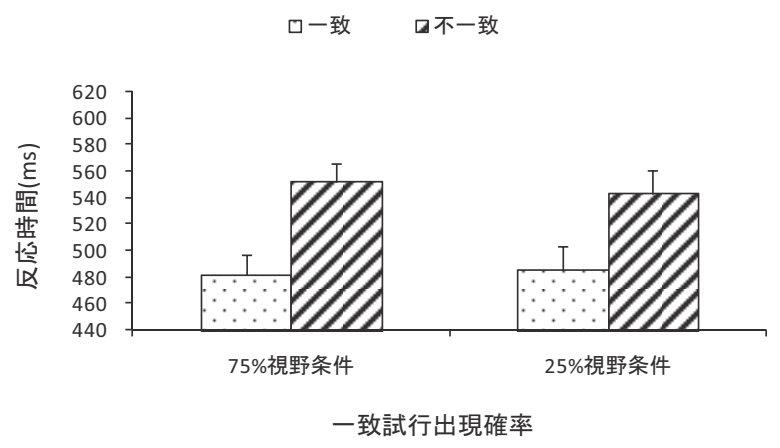

図 2 各条件における平均反応時間（バーは標準誤差）

\section{考 察}

本研究結果は蔵冨・吉崎（2010）を支持した。一致試行の 出現確率に応じた適合性効果の調整が, 左右視野において独 立して働くことが明らかとなった。このことは，視覚情報の 選択性の制御が各半球で行われている可能性を示唆している。

\section{引 用 文 献}

Corballis \& Gratton (2003). Biological Psychology, 64, 191-209.

Gratton, Coles, \& Donchin (1992). Journal of Experimental Psychology: General, 121, 480-506.

蔵冨・吉崎 (2010). 日本認知心理学会第 8 回大会発表論文集.

本研究は科学研究費補助金 (2153077 : 代表者 吉崎一人) の助成を受けた。 